Nina V. Kršljanin, Ph.D., Assistant Professor

University of Belgrade

Faculty of Law Belgrade

nina.krsljanin@ius.bg.ac.rs

\title{
THE SERBIAN ELECTIONS ACT OF 1870: AN ASSEMBLY'S THOUGHTS ON PARLIAMENTARY ELECTIONS*
}

\begin{abstract}
The Constitution of Serbia of 1869 (the so-called Regency Constitution) was the first Serbian constitution to give the Parliament (National Assembly) legislative powers, albeit inferior to those of the monarch. However, many important details regarding the parliamentary elections were not specified by the Constitution: for example, the length of the MPs' term or the question of secrecy of ballots. Due to various political reasons at the time of the passing of the Constitution, these issues were left for later legislation. Accordingly, the aforementioned and other matters were specified in the Elections Act of 1870, passed by the very first legislative assembly itself.

This paper will analyse the Elections Act itself and the debates in the National Assembly during its passing. It will particularly focus on issues that were hotly debated in the Assembly, as well as those where the Elections Act introduces a significant change to the constitutional framework. Finally, it will strive to explain the reasons for the introduction of particular institutions and to show how their creators (and opponents) expected them to influence the development of the Serbian Parliament.
\end{abstract}

Keywords: the Serbian Constitution of 1869, parliamentary elections, parliamentary debate, legislative power, length of term.

\section{INTRODUCTION: BRIEF BACKGROUND}

During the first half of the $19^{\text {th }}$ century the Serbian National Assembly was not a legislative organ, but merely an advisory one, having the power to decide in

* This article is the result of work on the project "Identitetski preobražaj Srbije" ("The identity transformation of Serbia") of the University of Belgrade Faculty of Law. Its draft version was presented at the $69^{\text {th }}$ conference of the ICHRPI Pouvoirs, débats, normes, held in Orleans and Paris (France), September 5-8, 2017. 
only a very limited number of issues. It was only after the assassination of Knjaz (Prince) Mihailo Obrenović in 1868 that ideas of parliamentary legislation were finally seriously considered. In order to pacify the growing liberal opposition and to secure the survival of the dynasty, the Regency of the underage Prince Milan Obrenović passed a new Constitution in 1869. It mostly represented a compromise between the conservative views of the regents themselves and the demands the liberals had been more or less actively making since $1858 .{ }^{1}$ Thus, it was through this Constitution that the Assembly received legislative powers for the first time. They were limited and inferior to those of the Prince, but this was still comparatively the greatest increase in the Assembly's power in Serbian constitutional history. ${ }^{2}$

\section{THE NATIONAL ASSEMBLY IN THE CONSTITUTION OF 1869}

The National Assembly was regulated in Part III of the Constitution (art. 4189), entitled O Narodnom predstavništvu (On the Representation of the People"). ${ }^{3}$ The National Assembly shared the legislative power with the Prince (art. 54). No statute could be passed, altered or abolished without its approval (except during great internal or external peril for the safety of the state, when the Prince had extraordinary legislative powers), but it had no legislative initiative: only the Prince could formally propose draft bills (art. 54-58). As Slobodan Jovanović remarked, this Constitution was filled with mistrust towards the Assembly's legislative capabilities, as it had until then been only a passive body. ${ }^{4}$ Furthermore, the Assem-

${ }^{1}$ For the details of these events, see Slobodan Jovanović, Vlada Milana Obrenovića I, BIGZ/Jugoslavijapublik/SKZ, Beograd 1990, 21-61; Živan Živanović, Politička istorija Srbije u drugoj polovini devetnaestog veka, knjiga prva: Od Sveto-andrejske skupštine do proglasa nezavisnosti Srbije 1858-1878, Izdavačka knjižarnica Gece Kona, Beograd 1923, 219-244; Dragoslav Stranjaković (prir.), Uspomene i doživljaji Dimitrija Marinkovića 1846-1869, Srpska kraljevska akademija, Beograd 1939, 206-211; Jovan Milićević, Jevrem Grujić: Istorijat svetoandrejskog liberalizma, Nolit, Beograd 1964, 175-194; for an analysis of different constitutional drafts, see Mirjana Stefanovski, Postanak Namesničkog ustava, Pravni fakultet Unvierziteta u Beogradu, Beograd 2016. For the personal view of the chief author of the Constitution, see Jovan Ristić, Jedno namesništvo 1868-1872, Štamparija Ljub. J. Bojovića, Beograd 1894, 32-53.

${ }^{2}$ Slobodan P. Orlović, Načelo podele vlasti u ustavnom razvoju Srbije, Pravni fakultet Univerziteta u Beogradu, Beograd 2008, 85-86.

${ }^{3}$ Zbornik zakona i uredba izdani u Knjažestvu Srbiji od početka do kraja 1869. godine, XXII, Državna štamparija, Beograd 1869, 44-92. For a modern edition see, e.g., Miodrag Jovičić (ur.), Ustavi Kneževine i Kraljevine Srbije 1835-1903, SANU / Naučna knjiga, Beograd 1988, 91111. As Slobodanka Stojičić has already remarked, this is the most detailed part of the Constitution, comprising over a third of the total number of its articles (133). Slobodanka Stojičić, Ustavni razvitak Srbije između namesničkog ustava i ustava od 1888. godine (1869-1888), doctoral dissertation defended at the University of Belgrade Faculty of Law, Beograd 1977, 25.

${ }^{4}$ Slobodan Jovanović, Velika narodna skupština: studija o ustavotvornoj vlasti (odštampano iz Braniča), Štamparija Svetozara Nikolića, Beograd 1900, 22-23. 
bly's budgetary power was limited (art. 63-65), and its control of ministers limited to accusing them of crimes against the State (art. 99-104). Some contemporaries condemned the constitutional position of the Assembly as illusory ${ }^{5}$, while others were confident that it was a good foundation to be further built upon ${ }^{6}$, but the fact remains that it was a significant improvement compared to its past consultative role and that it enabled it to "begin conquering the legislative function"

The composition of the Assembly was regulated in art. 42-53. The Assembly was composed of two categories of members: those "freely elected by the people" and those appointed by the Prince (art. 42). Art. 43 proclaimed the elections to be both direct and indirect, the latter through poverenici (lit. trustees, electors), but the Constitution made no mention of when which system was to be applied.

The number of MPs was flexible, relative to the number of voters: every srez (county) and okružna varoš (city that was centre of an okrug - district) ${ }^{8}$ was to elect one MP for every 3000 taxpayers, or at least one if the number was smaller than three thousand. ${ }^{9}$ Exceeding the quota by at least 500 taxpayers gave the srez or city the right to an additional MP. The capital city of Belgrade was to elect two

${ }^{5}$ See D. Stranjaković (prir.), Uspomene Dimitrija Marinkovića, 210-211.

${ }^{6}$ Stojan Bošković, "Prva zakonotvorna skupština", Za prosvetu i slobodu: članci i rasprave naučnog i političnog sadržaja iz ranijeg i poznijeg doba, Štamparija Zadruge štamparskih radenika, Beograd 1882, 54.

${ }^{7}$ Aleksandar Đurđev, "Srpski put od saborovanja do parlamentarizma”, Zbornik radova Pravnog fakulteta u Novom Sadu 2/2006, 91.

${ }^{8}$ Since the Candlemas (Sretenje) Constitution of 1835, Serbia had been divided into three levels, from the largest to the smallest: okrug, srez and opština, roughly translatable as district, county and municipality. After some attempts at modification, this division was finally firmly established in 1839. The Constitution of 1869 doesn't even prescribe it, relying in that respect on older laws. See Radoš Ljušić, Kneževina Srbija 1830-1839, Zavod za udžbenike i nastavna sredstva, Beograd 2004, 205-207; Ustrojenije okružn načalničestva, i glavne dužnosti srezski načalnika, Sbornik zakona i uredba, i uredbeni' ukaza, izdani' u Knjažestvu Srbskom, od vremena obnarodovanog Ustava zemaljskog (13. Fevr. 1839. do Apr. mes. 1840.) I, Knigopečatnja Knjažestva Srbskog, Beograd 1840, 78-83. The srez was already the tradtitional electoral unit according to previous laws; the largest unit, okrug, was not engaged in the electoral process as it was believed that voters could not know all the candidates from such a broad area in person. Živojin P. Ristić, Izborni zakoni Srbije: doktorska teza, Štamparija “Sv. Đorđe”, Beograd 1935, 59-60.

${ }^{9}$ When this article (art. 44) was being adopted in the Great National Assembly, deputy Pavle Radivojević, suggested a greater number of MPs (choosing one for every 2000 or 2500 taxpayers), stating that the people will be disappointed to see the number of MPs reduced. However, Radomir Milošević countered this with the argument that, as the Assembly would now be summoned every year, and not every three years, the number of MPs was, in fact, increased, and not reduced. The article was accepted without any changes. Protokoli Velike narodne skupštine držane 10. junija 1869. godine, u Kragujevcu, Državna štamparija, Beograd 1870, 55. Milošević's argument seems utterly invalid when one looks at the final solution of the Constitution - a mandate of three years: there would not be a greater number of MPs, their term would just last longer. However, one must keep in mind that this article came before the discussion regarding the length of term, and that it had by that time become customary in Serbia for MPs to be elected for every Assembly (every session), i.e. for a one-year term. Thus, it is likely that Milošević meant that a 
MPs regardless of the number of taxpayers. Once the number of elected MPs was determined in this way, the Prince could name a representative of his own for every three representatives elected by the people: it is expressly stated that he did not have to fill his quota. ${ }^{10}$ However, a special, albeit broadly formulated condition was set for them: they had to be chosen "from the ranks of people, who excel in science or experience in national affairs". ${ }^{11}$

Every man who was of age (21) and paid property, labour or income taxes had the right to elect MPs or trustees, or to be elected a trustee. As no minimal amount was specified, this was, as Slobodan Jovanović claimed, "a system very close to universal suffrage" 12 , at least for male citizens. As was to be expected, the conditions for passive suffrage were stricter ${ }^{13}$ : to be elected MP, one had to be at least 30 years of age, to pay 6 thalers of yearly taxes, as well as to fulfil any other conditions that were to be prescribed by an upcoming Elections Act. ${ }^{14}$

Some categories of people could not be elected, however: government officials and all who counted as such due to receiving any sort of regular payments (including pension or widowers' funds) from the fiscus, as well as attorneys, could not be elected by the people, although they could be appointed by the Prince. Soldiers in regular service, on the other hand, could not become MPs in either of those ways. While the restrictions for clerks and soldiers were placed for the usual reasons of maintaining the division of powers, as well as the political neutrality of those professions and avoiding a conflict of interests, the ban on attorneys was added by the Great National Assembly as it passed the Constitution. ${ }^{15}$

new Parliament every year, even with a reduced number of MPs, would in three years' time mean more elected MPs than a bigger Assembly that only met once every three years.

${ }^{10} \mathrm{It}$ is worth noting that in the first Assembly elected according to these rules the Prince (or, rather, the Regency) really did not name all the MPs he could: while 97 were elected by the people, he named only 18. In later years, the quota was usually more or less full. See the statistics in Ž. P. Ristić, Izborni zakoni, 3, fn. 1.

${ }^{11}$ Art. 45: ,...iz reda ljudi, koji se odlikuju naukom ili iskustvom u narodnim poslovima.“ It has been underlined by many authors that no body that would control the fulfillment of this condition was prescribed, so it was left to the Prince's judgement: e.g. Ž. P. Ristić, Izborni zakoni, 51; Miroslav Đorđević, "Istorijat izbora u Kneževini i Kraljevini Srbiji” in Oliver Nikolić, Vladimir Đurić (eds.), Izbori u domaćem i stranom pravu, Institut za uporedno pravo, Beograd 2012, 281.

${ }^{12}$ „....jedan sistem vrlo blizak opštem pravu glasa.“ S. Jovanović, Vlada Milana Obrenovića $I, 77$. Namely, according to the tax laws of the period, the state taxed every municipality per capita, but the municipality then split the amount it had to pay among its residents not equally, but according to their solvency. Thus, most people paid at least some amount of taxes. Ibid., 76-77. Bošković even believed that it was universal suffrage: Bošković, „Prva zakonotvorna skupština“, 81-82.

${ }^{13}$ Cf. Marijana Pajvančić, "Pasivno biračko pravo (poslanička sposobnost)" in Oliver Nikolić, Vladimir Đurić (eds.), Izbori u domaćem i stranom pravu, Institut za uporedno pravo, Beograd 2012, 19-21.

${ }^{14}$ Although none of these applied to those MPs appointed by the Prince; Ž. P. Ristić, Izborni zakoni, 51.

${ }^{15}$ It was suggested by Milosav Ristić, but supported by a large number of deputies. Protokoli $V N S, 56$. This dislike of attorneys was the result of peculiar historical circumstances. Namely, for 
The Constitution also pointed out that one could vote only in person and in only one polling place, that all MPs had to be residents of Serbia (although not necessarily of the county or city where they were elected), and that they represented the people as a whole and thus had free term. ${ }^{16}$ The text of their oath was also determined in the Constitution, as well as the way in which the Assembly and the Prince were to choose the chair and vice-chair of the Assembly. Finally, it was prescribed that a draft of the Elections Act for the National Assembly was to be presented to the first regular Assembly after the Constitution's passing.

As it can be seen, more than just the minute details of the elections process were left for the Elections Act to determine. The most obvious one was the length of the MPs term. The draft of the Constitution had contained a provision stating that MPs elected by the people had a three-year term, while those appointed by the Prince could be changed every year. The committee of the Great National Assembly that was reviewing the draft was going to suggest a one-year term for all MPs. However, after a discussion with the Government, they had come to a conclusion that it was best to leave this article out of the Constitution completely and later to regulate it by an Elections Act. The Assembly accepted their opinion and the length of term was not specified. ${ }^{17}$ The provision that was initially meant for the Constitution would later find its way into the draft of the Elections Act and provoke a lengthy discussion in the Assembly (see below). It seems that the Government was well aware that regulating this issue would take more time than most other constitutional matter (and, also, that the Great Assembly would be harder to convince to support its point of view than the ordinary one) and decided to speed up the passing of the Constitution by leaving it to subsequent legislation.

Another relevant question left unmentioned by the Constitution was whether the voting was to be public or secret. However, this was not included in the draft nor mentioned during the sittings of the Great Assembly. As Slobodanka Stojičić remarks, both of these questions belong by their nature to constitutional matter,

about two decades, there were no formal conditions for one to become an attorney, other than the proscription of simultaneously being in service to the State. As most educated people were employed as state clerks, this led to the appearance of many incompetent, corrupt or outright fraudulent attorneys. Although the situation had significantly improved during the 1860 s, the bad memory was to persist for a long time afterwards. See Živojin Šestić, "Advokatura u Srbiji do 1918 godine", Istorija jugoslovenske advokature I, SAKJ, Beograd 1998, 163-178, Zoran S. Mirković, Srpska pravna istorija, Pravni fakultet Univerziteta u Beogradu, Beograd 2017, 190-194 and Gordana M. Drakić, „O advokaturi u međuratnoj jugoslovenskoj državi“, u Harmonizacija srpskog i mađarskog prava sa pravom Evropske Unije: tematski zbornik, knjiga V, Pravni fakultet u Novom Sadu, Novi $\operatorname{sad} 2017,368$.

${ }^{16}$ Irena Pejić seems to believe that this freedom was dampened by the public ballots. Irena Pejić, „Parlament u Srbiji i pravni položaj narodnih poslanika“, in Aleksandar Fira, Ratko Marković (eds.), Dva veka srpske ustavnosti, SANU / Pravni fakultet Univerziteta u Beogradu, Beograd 2010, 140.

${ }^{17}$ Protokoli VNS, 57. See also Stefanovski, Postanak, 156; Stojičić, Ustavni razvitak, 31, 35. 
and should have been regulated by the Constitution itself - but they were delegated to an ordinary act for practical political reasons. ${ }^{18}$

In accordance with the temporary provision of art. 133 of the Constitution, the first Assembly was elected by the old electoral system, and held in Kragujevac from September 14th until October 25th, 1870..$^{19}$ It consisted of 121 MPs: 97 were elected, while the Regency appointed $24 .{ }^{20}$ Its main task was to pass a number of organic (constitutional) acts, including the Elections Act. ${ }^{21}$

\section{THE ELECTIONS ACT OF 1870}

A committee formed by the Government drafted the Act. ${ }^{22}$ The legislative committee of the Assembly delivered its report regarding the Elections Act to the plenum on October 3rd, 1870; the brief parliamentary debate took place on October 5 th and 6 th.$^{23}$ The Act was finally promulgated on October 10th, $1870 .{ }^{24}$ In its final form, it consists of 83 articles, divided into 12 (non-numerated) sections or chapters, each detailing a phase in the elections process, and the last one peculiarities regarding the Great National Assembly. ${ }^{25}$

${ }^{18}$ Stojičić, Ustavni razvitak, 40.

19 Boro Majdanac, Narodna skupština Srbije: od običajne ustanove do savremenog parlamenta 1804-2004, Narodna skupština Republike Srbije / Arhiv Srbije, Beograd 2004, 37. At the time, the Julian calendar was in use in Serbia, and the dates are given in accordance with it.

${ }^{20}$ Although it could have appointed up to 32. Čedomil Mitrinović, Miloš N. Brašić, Jugoslovenske narodne skupštine i sabori, Narodna skupština Kraljevine Jugoslavije, Beograd 1937, 81.

${ }^{21}$ Stojičić, Ustavni razvitak, 34-35. For more details on this Assembly's work see Miroslav D. Pešić, „Prva zakonodavna skupština u Kneževini Srbiji i donošenje organskih zakona iz 1870. godine“, Zbornik radova Filozofskog fakulteta u Prištini, XLIV(2)/2014, 163-175 and Mitrinović, Brašić, Jugoslovenske narodne skupštine, 81-85.

${ }^{22}$ Its members were Jevrem Grujić, Danilo Stefanović and Kosta Magazinović. Pešić, „Prva zakonodavna skupština“, 168; Milićević, Jevrem Grujić, 202-203.

${ }^{23}$ Generally, the debates regarding all the laws this Assembly was to pass were comparatively short, with a proper discussion arising only upon a few key issues. This might have been partially caused by the MPs' understanding that they have a duty to pass a large number of important laws in a short period of time, but also partially by their (prevailingly) low levels of education and lack of experience in parliamentary procedure. That is not to say that detailed analyses didn't exist outside the Assembly: for example, Stojan Bošković published an article in 11 parts in the paper Srbija (Serbia) in October 1870, outlining in detail his views on how the Assembly should regulate the most important issues left open by the Constitution, including elections. Bošković, „Prva zakonotvorna skupština“.

${ }^{24}$ Protokoli, 98, 106, 118, 134, 191. The committee was formed on September 27th, according to the freshly adopted rules of procedure, and was composed of: Stojan Veljković, Božo Božović, Vaso Madžarević, Pavle Grković, Nikola Colović, Vladimir Hadžić, Despot Vučićević, Sima Živković and Nikola Mandić. Ibid., 76. The reporting MP for this Act was Dimitrije Jovanović.

${ }^{25}$ Zbornik zakona i uredba izdani u Knjažestvu Srbiji za 1870 godinu, XXIII, Državna štamparija, Beograd 1870, 64-88. 


\subsection{Length of term}

The first section, Kad se biraju poslanici ("When are the members of Parliament elected" - art. 1-4) covers the most basic provisions. General elections were to be held on every fourth year, i.e. the term was three years. The first elections according to this Act were to be held during the following year, 1871. Supplementary elections ${ }^{26}$ were to be held either during a session of the Assembly, or just before its convocation. Either way, the elections were to be ordered by the Prince on the initiative of the Minister of Internal Affairs, and after the hearing of the entire Ministerial Council (Government). The decree was to be published in the official gazette and every srez and city - or, in the case of supplementary elections, in those where the elections were to be held. At least a month's time had to be left between the publication of the Prince's decree and the general elections, but there was no such need in the case of supplementary elections for an ongoing Assembly.

The act, thus, shows implicitly that the length of mandate for all MPs, elected or appointed by the Prince, was the same. However, according to the provisions of the original draft, the Prince's representatives were to be appointed every year. The first and most important change to the draft suggested by the parliamentary committee that was analysing it was to extend the term to three years. (There were also two minority opinions- one that found the draft acceptable and one that thought that it would be better for all MPs to be elected for only one year.) The main reasons for this put forward by the committee were: 1. that MPs gain more skill and experience and thus work better if they take part in multiple assemblies instead of being chosen anew every year; 2 . that a longer term gives MPs a chance to understand connections between acts they are passing through the years, which is beneficial both for their noticing potential problems with an individual act and for maintaining a consistent legislative policy; 3 . that MPs with a longer term would have a stronger will and devote more attention to fixing current problems within the country, while those who were changed every year would be always unprepared for solving public problems. ${ }^{27}$ This issue caused a long and heated debate in the Assembly, with all three opinions represented in it. ${ }^{28}$

The main arguments of those in favour of the one-year term for the Prince's MPs were minimising the executive's influence over the MPs and insuring their maximum competence. Those who wanted the elected MPs term to be reduced to a single year as well were focused on not letting them become overconfident and

\footnotetext{
${ }^{26}$ Serbian terminology of the time does not differentiate between supplementary elections and by-elections.

${ }^{27}$ Protokoli, 107-108. Most of the other changes suggested by the committee were matters of style and terminology.

${ }^{28}$ Protokoli, 118-128.
} 
too distanced from the interests of the people, as well as on the idea that equal length of term was better. For example, Pavle Radivojević, who was the first to speak in the debate, pointed out that if the Prince's MPs were elected every year, the government would have less influence over them, and suggested the same for the representatives of the people. He acknowledged, however, that MPs would be more skilful and freer in their speech if their term was longer, confessing from his own experience that he was always silent in his first Assembly, but spoke out in the second and third. Despite that, he believed that MPs with a longer term could start thinking too highly of themselves and thus become unpopular among the people, and so was in favour of yearly elections. Mile Damnjanović seconded his proposal, underlining that the three years' term was not fixed in the constitution and expressing his fear for the interests of the people if the MPs were elected for three years. Đorđe Maletić believed it was better to change the Prince's MPs yearly in order to have the most competent people, and that the others should have the same term for parity's sake. Bishop Moses (Mojsije) claimed that, as the Assembly was a sort of a school for legislators, yearly elections would lead to there being a greater number of capable and skilled individuals among the people. Nenad Mihailović and Teofilo Sandić believed that a three-year term would temporarily prevent younger and more capable people of entering the Assembly.

On the other hand, some MPs considered the concept of the draft to be quite valid - one year for those MPs appointed by the Prince and three for those elected. ${ }^{29}$ Anta Pantić, for example, believed that a three-year term was better for elected MPs, but that the Assembly had no right to command the Prince on how to choose his MPs, as the Constitution gave him freedom of choice there.

Those in favour of the committee's proposal pointed out the quality and efficiency of the Parliament's work, but also economic, historical and comparative reasons. Boža Božović pointed out that yearly elections would put a great strain on the economy. Alimpije Vasiljević, secretary of the Assembly, pointed out that assemblies elected for one year were acceptable when their role was merely to express the wishes of the people, but that now that the National Assembly had become a legislative body that was no longer the case. MPs had to be well prepared for such an important job, and a longer term meant better preparedness, more time and will for the MP to study the existing laws, deduce what should be changed and what new laws were needed. He pointed out that all enlightened countries with legislative assemblies elected their representatives for longer terms, highlighting England as the most advanced with a term of seven years. ${ }^{30}$ Still, his exposition also showed the strong opposition between the government and the

${ }^{29}$ Vladimir Hadžić, Todor Mirković supported this view as well, but brought up no significant new arguments.

${ }^{30}$ Vasiljević's wording, of course, was colloquial and thus imprecise - he meant the United Kingdom. 
people: "If this Assembly would itself ask for the deputies to be elected for a term of three years, then it would be working in the interest of the people, and if it refused that, then it would be working more in the interest of the government." 31 Jovan Bošković, also a secretary, countered the argument that a three-years term would lead to excessive independence of the MPs, stating that it would be exactly the opposite. ${ }^{32}$ Ilija Protić agreed with Vasiljević, adding that although some believed that the Prince's MPs, as learned men, would not have to prepare for the parliamentary debates, that was not the case, as being prepared for the office and for the Assembly was not the same. Vaso Madžarević pointed out that there could be no abuse of power by MPs with a longer mandate, since if such a thing happened, the Government could always use its right to dissolve the Parliament, claiming also that a three-year term would give the Prince's MPs a greater degree of autonomy. Jovan Valenta gave a lengthy exposition on how a longer mandate was morally and economically better for the people (also underlining comparative experience), pointing out that the freedom of press (proclaimed by the Constitution for the first time) would help keep the wilful MPs in check, and that there was nothing wrong with the people treating deserving MPs with a higher degree of respect. Dimitrije Jovanović compared a three-year term Assembly to a river with a steady course, and a one-year one to a dangerous and unpredictable current. Dragutin Riznić claimed that no Assembly (meaning the recent assemblies in Serbia) had ever worked against the interests of the people and that thus there was no reason to fear the MPs behaviour no matter how long their term, but desired to hear the opinion of the President of the Ministerial Council (Prime Minister). ${ }^{33}$

Radivoje Milojković, Prime Minister and Minister of Internal Affairs ${ }^{34}$, stated that the length of term was one of the most important issues of the Elections Act and that he would have spoken about it even if Riznic had not asked for it. According to Milojković, the numerous reasons pro et contra could be summed up into two main ones: MPs being as prepared for their task and as independent as possible. The first goal would be accomplished by a longer term, as MPs who

${ }^{31}$ „Kad bi ova skupština sama tražila da se poslanici biraju na tri godine, to bi ona radila u interesu naroda, a kad bi odbila onda bi radila više u interesu vlade." Protokoli, 121.

${ }^{32}$ Most likely, he meant that having to prepare for elections every year would lead the MPs to focus on catering to the voters instead of their legislative work.

33 The committee's view was also supported by Panta Srećković and Nikola Colović.

${ }^{34}$ Milojković was a renowned lawyer and politician at the time; he studied law in Heidelberg and Paris and had held various important posts prior to his service as minister: for a while, he was the Secretary of the Ministry of Justice, Secretary of the State Council and the President (Chair) of the Appellate Court. He wrote a constitutional draft in 1867, and took part in writing the Constitution of 1869, which was partially based on his earlier draft. See Milićević, Jevrem Grujić, 190-195, Aleksandra Vučetić, Ljubinka Trgovčević, "Autobiografske beleške Radivoja Milojkovića" in Petar V. Krestić (ur.), Mešovita građa (Miscellanea) XXI, Istorijski institut, Beograd 2003, 61-87 and Mirjana Stefanovski, „Nacrt ustava Radivoja Milojkovića iz 1867. godine“, Zbornik Matice srpske za drušvene nauke 138/2012, 1-16. 
attend the Assembly a greater number of times would be better prepared, but they would also have more time and motivation to get to know the general (instead of just the local) interests of the people. The second goal, he claimed, would obviously be better fulfilled with MPs who know that their seat is secure for three years. He underlined that the people would hardly (only as a rare exception) elect MPs who would work against their best interests, and that as the Assembly could control the Government, not letting it hinder the interests of the people, all the more it could control such an MP. ${ }^{35}$ The influence of such deputies on the people could, again, be only positive. He finished with stating that the Government was doing a great service to the country by proposing a longer term for MPs, so that someone could preserve the direction the Government had taken with the support of the people. After a few more remarks and statements of patriotism and support to the Government ${ }^{36}$, as well as the Prime Minister's thanks for the Assembly's trust, the matter was put up for voting. Even the previous opponents of the board's idea voiced out that they now understood it to be better for the people, and the article was accepted unanimously. ${ }^{37}$

Of course, the debate also contained some misplaced arguments that were easily countered by those of dissenting opinions. For example, Boža Božović, speaking in favour of the three-year term, claimed that a tradition of longer terms existed during the first reign of Prince Miloš Obrenović. That argument was easily refuted by Bishop Moses, who remarked that those deputies were not elected by the people, but appointed by Miloš himself. ${ }^{38}$ Nikola Mandić favoured a one-year term out of fear that the people would think that the current MPs were working for their personal gain if they set a three-year term. Vaso Madžarević reminded him that such a thing could not happen, as it was expressly stated that the Elections Act did not apply to the current MPs, but that a new election according to it would be held next year.

It is also worth noting that the slightly confusing phrasing of art. 1, "every fourth year" ("svake četvrte godine"), was, in fact, a modification of the Assembly.

35 This statement was not quite true: as stated before, ministers were only criminally liable before the Assembly.

${ }^{36}$ From Arsa Lukić, Kosta Dimitrijević and Kasijan Stojšić. Dimitrijević had even stated that he had voted against the proposal in the committee, but that he was convinced now and would support it.

${ }^{37}$ Slobodanka Stojičić points out that "the ordinary National Assembly had agreed to what the Great National Assembly would not agree to.“ („,Obična narodna skupština pristala je na ono na šta velika narodna skupština nije htela da pristane.") Stojičić, Ustavni razvitak, 43. Perhaps it would be better to say - to what the Great Assembly was not inclined to agree to. After all, we cannot know how the debate would have developed had the matter originally been put up for voting.

${ }^{38}$ In fact, some of them were elected and some appointed by the Prince. See Ljušić, Kneževina Srbija, 220-224; Ljubica Kandić, "Delatnost skupština za vreme prve vlade Miloša Obrenovića”, Anali Pravnog fakulteta u Beogradu 1/1961, 55-68. 
The initial draft said "every third year"; but during the discussion about the tenth section, where it was stated that elections were valid for three years (see below), Dimitrije Milojković stated that those two phrasings were at odds with each other. He suggested that it be said "every third year, not counting the one the elections were held in", but MP and secretary Alimpije Vasiljević corrected that to "every fourth year", and the article was adopted in that form. ${ }^{39}$

\subsection{Deputy and voter lists, active and passive suffrage}

The second section of the Act, Spisak o broju poslanika "The list on the number of members of Parliament" - art. 5-6) proclaims that after the Prince's decree, the Minister of Internal Affairs would publish a list on the number of MPs, detailing the number of taxpayers in each electoral unit and the number of MPs derived therefrom, as well as the number of those then to be appointed by the Prince. Any objections regarding the determined number were to be brought before the (current) National Assembly.

The third section, Spisak birača („List of voters“ - art. 7-16), concerns not a centralized list made by the government (as in the case of the list on the number of MPs), but local lists of voters kept for every electoral unit. These alphabetical lists were kept by municipality courts, which had a duty of forming them within 10 days of the publication of the Prince's elections decree. The list was available for any interested party to see within the court, and its existence was to be announced through locally appropriate means. Once the lists were compiled for the first time, the courts were only to modify them for subsequent elections by adding or erasing voters as necessary.

Any man could file objections to the list, oral or written (but backed by valid documentary evidence in either case), within 8 days of its publishing, demanding that the list be altered or for the court to explain why this wouldn't be possible, again within 8 days. If the party was not satisfied with the municipality court's decision, they could appeal to a district court, and then to the Court of Cassation, again within the same deadline. Any decision was to be communicated not only to the person who filed the objection, but also to the persons concerned (i.e. those whose place on the list was disputed). After a final decision was passed, the list was to be amended according to it "right away" (odma). The same instant-deadline was prescribed for the obtaining of documents one needed to prove his right to vote or be elected from a priest or municipality court. ${ }^{40}$ All in all, this was a great improvement compared to previous legislation: voter lists were introduced

${ }^{39}$ Protokoli, 132-133.

40 Proof of one's date of birth in the given period was a record of baptism, kept by parish priests. 
in Serbia for the first time in 1861, but they were regulated in much less detail and they were kept by the police authorities. ${ }^{41}$

Conditions for active and passive suffrage were covered in more detail in the fourth section, Ko može biti birač, poverenik ili poslanik ("Who can be a voter, trustee or member of Parliament" - art. 17-23). The regulation of active suffrage merely repeated the conditions determined by the Constitution (even referring to its art. 46), but with some additions. It was underlined that persons exempt from paying taxes by legal provisions did not lose their suffrage because of it. Certain categories of the population were denied active suffrage: roaming Gypsies ${ }^{42}$; people in the employ of another (such as servants and apprentices, who paid a special sort of tax-bećarski danak ${ }^{43}$ ); those convicted of any felonies (zločinstvo) and those transgressions (prestup) that were followed by a loss of honourable rights ${ }^{44}$, for the length of that measure and during incarceration ${ }^{45}$; those convicted for having attempted to influence their own or another's election through illicit means, or having sold their vote, for the length of time determined in the verdict; persons undergoing bankruptcy, until the procedure was over; persons under guardianship; and, finally, those denied suffrage by art. 48 of the Constitution (clerks, attorneys and soldiers).

To be included into the list of voters, one had to reside in a certain municipality either during the creation of the list or at the time of the elections. Voting was possible only in the municipality where one was included in the list. Passive suffrage, on the other hand, was not restricted by one's place of residence - as long as, as the Constitution demanded, the candidate in question was a resident of Serbia - so the same person could run for MP in multiple electoral units simultaneously. If he was elected in multiple units, he had to choose right away which election he would accept ${ }^{46}$ Candidacy was individual - registration of political parties would not be allowed in Serbia until 1881 (although, of course, political

${ }^{41}$ Appeals were also directed to higher administrative organs (up to the Ministry of Internal Affairs), and not to courts. Ž. P. Ristić, Izborni zakoni, 38-40, 61-62.

42 As they had no permanent place of residence, they paid a specific per capita tax. Drag. M. Milojević, Neposredni porezi Srbije i Kraljevine Srba, Hrvata i Slovenaca, Zemunska štamparija GS SZZ, Beograd 1925, 10, 18, 26.

${ }^{43}$ Literally 'bachelor tax', this tax was paid by unmarried men who served in the employ of others and usually had no house or land of their own - servants, waiters, artisans' apprentices, tradesmen's assistants etc. Ibid., 17-18, 26.

${ }^{44}$ The Serbian Criminal Code of 1860 adopted the model present in the Prussian and, before it, French criminal codes, of categorizing crimes into three groups according to their severity: zločinstvo or zločin (felony), prestupljenje or prestup (transgression) and izstupljenje or istup (misdemeanour). See art. 1 of the Code, Kazniteljnij zakonik za Knjažestvo Srbiju, Praviteljstvena pečatnja, Beograd 1860, 1.

${ }^{45}$ For some examples of such cases in practice, see Ž. P. Ristić, Izborni zakoni, 47-49.

${ }^{46}$ The Act does not specify what would happen in the other units, but it is clear that the second-best candidate would then count as elected. 
groups that would form the basis for the later parties were already forming), so there could not be any party lists. ${ }^{47}$

No additional conditions were prescribed for passive suffrage. On first sight, it might seem that the Elections Act overstepped the boundaries set by the Constitution, as it added nothing to the conditions for passive suffrage, which the Constitution explicitly allowed it to do, but expanded those for active suffrage, where it had no such authorisation. However, such a judgement would be too strict. The seeming expansion of the conditions for active suffrage was merely an extensive elaboration of what was already implied by existing rules. And the fact that the Constitution indicated that the Elections Act would prescribe additional conditions for passive suffrage was, obviously, only an authorisation, and not an obligation.

\subsection{Electoral procedure}

The fifth section, Neposredno i posredno biranje narodnih poslanika ("Indirect and direct election of the members of Parliament"), consists of only a single article - art. 24, proclaiming that MPs are elected directly in all district cities, but indirectly in counties. ${ }^{48}$ The following two sections - essentially, the central sections of the Act - contain detailed procedural rules for each of those types of election respectively.

The sixth section, Postupak pri biranju u okružnim varošima ("Procedure during elections in district cities" - art. 25-51) is the longest one in this Act. After the publication of the Prince's decree, the municipality courts in cities were to announce the exact date, time and place of elections in their city through written and oral announcements, and newspapers, in those cities where they were printed. The place of voting had to be the seat of the municipality court.

On the appointed day, the elections, also called an 'electoral assembly' (izborna skupština), started at eight o'clock in the morning, chaired by the head (president) of the municipality court. As soon as at least 20 voters were gathered, they were to choose 4 members of the elections board (committee ${ }^{49}$ ) that was to oversee the elections under the chair of the same president of the court, deciding by majority vote..$^{50}$ Municipality officials could take part as scribes or clerks, but

${ }^{47}$ For more details on the inception of political parties in Serbia, see Dragoslav Janković, Rađanje parlamentarne demokratije: Političke stranke u Srbiji XIX veka, Pravni fakultet Univerziteta u Beogradu, Beograd 1997.

48 The initial draft made by the committtee headed by Grujić prescribed direct elections everywhere, but the Government subsequently altered this. Milićević, Jevrem Grujić, 202-203.

${ }^{49}$ To avoid confusion in the text, this body will be referred to as a board, while the legislative and other auxiliary bodies of the Assembly will be referred to as committees. The Serbian acts of the period used the word odbor in both cases.

${ }^{50}$ A proposal to have the chair of the board elected instead had been put forward both in the committee and the Assembly by MP Nikola Colović, but the Prime Minister remarked that "it 
that did not give them a vote unless they were also elected members of the board. The chair of the board was in charge of maintaining order within the building, but could demand the help of state organs if he was unable to do so himself. The court was also obliged to supply anything necessary for the board's activities. At least three members of the board had to sit at the voting table at all times. The initial draft had prescribed that only two members of the board would be chosen (in addition to the chairman), and that two of them would have to be present at the table. The legislative committee suggested an increase to 4 and 3, respectively, explaining that a larger board would be better, as it was less likely to be influenced by the chair, and it would be more convenient for some members to temporarily take their leave without jeopardising the control of the voting. ${ }^{51}$

The ballot was public: a voter approached the table and declared the person or persons (if the city elected more than one MP) he was voting for. Members of the board wrote his name down on a sheet of paper devoted to the candidate in question (unless the voter was willing and able to do so himself), and marked the voter in the alphabetical list as having voted. There were no objections to the public ballots during the parliamentary debate, which might strike one as peculiar. It must be kept in mind, however, that not only was public voting already an established tradition at the time, but that many politicians and lawyers even near the end of the 19th century believed that it stimulated the voters' courage and moral superiority, while secret ballots promoted weakness of character. ${ }^{52}$

The voting took place until sundown. ${ }^{53}$ (The draft had even prescribed the possibility of two consecutive days' ballots, but the legislative committee was opposed to that, stating that in Serbian conditions it was easy to hold the elections in one day, and that the opposite would open the path to various forms of abuse. ${ }^{54}$ ) The board was then to proclaim the ballots to be closed, sew all the candidates' sheets together, mark them with page numbers and add a blank piece of paper in the end. Onto this paper they would copy the names of all the voters from the alphabetical list who had voted, and sign their own names. Then they would commence to count the votes.

If one of the candidates had received, as it is phrased, "a perfect majority", i.e. more than $50 \%$ of all given votes, he was automatically elected and the board would proclaim that right away. If there was no such candidate, the board would

wouldn't be political“" to express mistrust towards a man chosen by the people, all the more given that he could not affect the voters nor the other 4 members of the board. After such remarks, the article was accepted as the committee had drafted it. Protokoli, 128-129.

${ }^{51}$ Protokoli, 110. The same applies to the boards in the case of indirect ballots. Ibid., 112.

${ }^{52}$ Ratko Marković, Ustavno pravo, Pravni fakultet Univerziteta u Beogradu, Beograd 2017, 234.

${ }^{53}$ It is peculiar that the Act prescribed a fixed hour, 8 A.M., as the start of voting, but a shifting astronomical one (sunset) as its end.

${ }^{54}$ Protokoli, 110-111.Thus various more detailed provisions regarding the second day were removed completely. 
proclaim two candidates who had received the most votes - or more than two in the case of a tie. In such a case, the elections would be repeated with only those candidates at least three days later ${ }^{55}$, according to the same procedure, but requiring only a simple majority. Thus, the Act applied a two-ballot majority system ${ }^{56}$, similar to the one used in Belgium since the Constitution of 1831, only without political parties. ${ }^{57}$ Generally, the purpose of two-ballot systems, even when absolute majority is not required in the second ballot, is to avoid the existence of MPs supported only by a minority in their constituency. ${ }^{58}$ Again following the Belgian model ${ }^{59}$, the Act prescribed that, in the case if the second ballot ended with a tie, the oldest of the tied candidates would be considered elected. The draft had actually suggested determining the results randomly, through a roll of dice (which one might consider to be more democratic), but the legislative committee altered this, claiming that it would make people think of gambling, which they were ill-disposed towards. ${ }^{60}$ In a mostly rural and patriarchal society, the notion seems highly reasonable.

Further, art. 47 specified that the National Assembly would decide on whether the elected candidate could be accepted as an MP, i.e. whether all the conditions were fulfilled. Voters had the right to witness the writing down and subsequent counting of votes. They or the police authorities had the right to file complaints against the decisions of the board in the case of any irregularity during the elections process. Complaints could be delivered to the board itself or directly to the National Assembly.

After every elections day, the board would make a report which would be published in the same way as the announcement of the elections, containing the total number of voters in the city, the number of those who had voted, the number required for the perfect majority, the names of elected MPs and, if there was no perfect majority, the names of the candidates with the most votes and the place, date and time for the new elections. They would also compile a detailed record of the elections which was to be sewn in with all the documents used, including any

${ }^{55}$ The Assembly added this period with the remark that the day of the initial elections didn't count. Protokoli, 129.

${ }^{56}$ R. Marković, Ustavno pravo, 236; David M. Farrell, Comparing Electoral Systems, Macmillan Press, Basingstoke - London 1998, 40-45. Some consider even absolute majority systems it to be a variation of the 'first-past-the-post' system: e.g. Philip Laundy, Parliaments in the Modern World, Interparliamentary Union / Darthmouth Publishing, Aldershot - Brookfield 1989, 15-17.

57 Andrew McLaren Carstairs, A Short History of Electoral Systems in Western Europe, George Allen \& Unwin, London - Boston - Sydney 1980, 50; Dieter Nohlen, Heidemarie Opiela, "Belgien" in Dolf Sternberger, Bernhard Vogel (Hrsg.), Die Wahl der Parlamente und anderer Staatsorgane: Ein Handbuch, Band I: Europa, Walter de Gruyter \& Co., Berlin 1969, 78-79.

58 A. McLaren Carstairs, A Short History of Electoral Systems, 10.

${ }^{59}$ D. Nohlen, H. Opiela, "Belgien", 79.

${ }^{60}$ Protokoli, 111. 
complaints that might have been filed, and sent to the National Assembly within five days. The board would also issue credentials (punomoćja) to the elected MPs based on the record.

The seventh section, Postupak pri biranju u srezovima ("Procedure during elections in counties" - art. 52-70) is somewhat shorter than its predecessor, as many of its provisions merely refer to the procedure prescribed for district cities. The main difference, still, was the indirect voting. Every municipality within the county - or, rather, its 'electoral gathering' (birački zbor) - would elect 2 trustees for every 50 voters in the municipality, with a minimum of 2 even if there were less than 50 taxpayers. The election of trustees was to be performed (also under the chair of the president of the municipality court) before the term of the final elections set in the Prince's decree, but no other timeframe was given. The election of trustees was simpler than that of MPs, since a simple majority was sufficient and new elections were necessary only in the case of a tie.

Still, what sparked a discussion in the Assembly was the electoral unit. ${ }^{61}$ An alternative to the municipality was the village: some MPs believed it to be more practical. Aleksa Petković stated that it would be easier for the voters and that they would waste less time (going to the seat of the municipality) if the elections of trustees were held in every village. Secretary Jovan Bošković agreed with that, stating that otherwise smaller villages would never have a trustee of their own. Panta Srećković pointed out that those in favour of municipalities are MPs who live in the plains, where villages are large and close to each other, but that they do not take into account scattered villages in inaccessible areas. ${ }^{62}$

Others, however, were against such extremely localised elections. Anta Pantić pointed out that they would even be impossible, as there were no literate people in some villages, and the village authorities had no official seal to authorise the elected trustees with. Several MPs ${ }^{63}$ stated that trustees elected in villages would be distanced from legal authorities. Milovan Spasić suggested that not all villagers would have to go to the municipality and leave their work, but that they could choose a few people to go in the name of the whole village. Jevrem Barlov pointed out (albeit wrongly) that if elections were on the level of village, villages with less than 50 taxpayers could not take part at all. ${ }^{64}$ Still, the discussion was ended by the Prime Minister, who explained that the municipality was the smallest political unit in the country, and that the Elections Act could not divide it further,

\footnotetext{
${ }^{61}$ Protokoli, 130-132.

62 Other MPs who voiced their opinions in favour of this were Pavle Radivojević, Nikola Mandić and Gaja Popović.

${ }^{63}$ Božo Božović, Milan Stojić-Učiteljević and Todor Mirković.

${ }^{64}$ The view in favour of municipality elections was also supported by Dimitrije Jovanović, Dragutin Riznić, Vićentije Starčević, Ivko Ostojić and a certain Vujičić, who is nowhere mentioned by his full name.
} 
especially not into units as small as 10-15 people. He underlined that such a regime had already been in force and that there were never any complaints regarding irregularities of such elections. ${ }^{65}$

The elected trustees were to come to the place of elections either in the company of the chair who presided over their choosing, or with a letter from the electoral board. The option of a letter was added by the legislative committee, which believed that the alternative could potentially be easier for the municipality ${ }^{66}$ All trustees for a certain county comprised the county electoral assembly (izborna sreska skupština), whose task was to elect MPs for the National Assembly. Every chair of a municipality electoral gathering would report the results of the election of trustees in his municipality (the total number and turnout of voters and the names of trustees) in person or in writing.

The electoral assembly was to be presided by the head of the municipality court of the municipality in which the assembly took place, or the eldest among the trustees if it took place in the district city. Just like with direct elections in the cities, as soon as 20 trustees were present, they would choose 4 members for the electoral board, which functioned in the exactly same way as for direct elections. The voting procedure was also mostly similar, with only a few differences. Firstly, the voting would last the whole day only if there were trustees present and actively voting: if there were none who hadn't voted by 4 o'clock in the afternoon, the voting would be closed then, or as soon afterwards as no more trustees were there to vote. Secondly, if there was no perfect majority, the additional elections between the two top candidates would take place right away, without postponing. Finally, the details regarding the record the board was to comprise were different in accordance with the difference in the type of elections.

\subsection{Other provisions}

The brief eighth section, Kazni za zloupotrebe pri biranju ("Penalties for abuse during elections" - art. 71-72) contains the most frequent breaches of honest procedure for the period. Any person who would give, offer or accept a bribe or threaten someone to vote for a particular candidate or to abstain from voting would be punished by imprisonment (zatvor) up to one year, as well as loss of active and passive suffrage for up to the next three general elections. This last penalty was added by the legislative committee, which considered it to be "quite appropriate for the crime in question." ${ }^{67}$

${ }^{65}$ Naturally, there were plenty of irregularities, including direct interventions of the government (see e.g. Bošković, "Prva zakonotvorna skupština", 73-78), they were just unrelated to the size of the electoral unit.

${ }^{66}$ Protokoli, 112.

${ }^{67}$, ,...baš odgovara samom prestupu.“ Protokoli, 113. 
Any person attending any phase of the elections armed would be merely removed from the place of voting by the chairman. No actual penalty was prescribed. That is surely due to the fact that, in the previous period, it was common for men (particularly men of note and in rural areas) to carry arms at all times, including to the sessions of the Assembly. This was already forbidden (both when attending elections and the Assembly itself) by the National Assembly Act of 1861, but the ban had obviously not taken root to a sufficiently reliable degree. ${ }^{68}$

The ninth section, O poslanicima koje Knjaz bira ("On the members of Parliament chosen by the Prince" - art. 73-75) explains a very short and simple procedure: upon hearing out the Ministerial Council and upon the proposal of the Minister of Internal Affairs, the Prince would issue an act listing his choice of MPs. The act would then be published in the official gazette. The Minister would send the act to the National Assembly along with the records of all the elections in the country, and issue credentials to the MPs on its basis.

The tenth section, Za koliko vrede izbori ("For how long are elections valid" - art. 76-79), provides more details regarding the MPs' term and extraordinary elections that were only briefly outlined in the first section. It proclaims general elections to be valid for 3 years, counting from the beginning of the year in which they took place, regardless of whether they were regular or called because of the dissolution of the National Assembly. It is worth noting, however, that an MP chosen by the Prince, whose official position changed during his term, could not keep it without being appointed anew. This provision was added by the legislative committee, which believed that during a three-years term (not one year, as the draft originally intended), an MP's position could undergo significant changes, causing incompatibility with his parliamentary position through great dependence on the central government or for other reasons.

An irregular session of the Assembly convoked in the elections year could be composed of the members of the old assembly, without it precluding the regular general elections. Naturally, any supplementary elections were valid only until the first following general elections. If an MP fell ill, no new elections would take place except by decision of the Assembly. In the case of an MP's death, his place was to be filled by new elections before the next session of the Assembly; if the place was voided for any reason other than death, new elections were to be held only after the Assembly declared the seat void. If the MP had been appointed by the Prince, the Prince would decide on whether to name a new one.

\footnotetext{
${ }^{68}$ Pavlović points out that the disarming of deputies was a prerequisite for having a modern parliament. Marko Pavlović, "Narodna skupština u ustavima Kneževine i Kraljevine Srbije”, in Aleksandar Fira, Ratko Marković (eds.), Dva veka srpske ustavnosti, SANU / Pravni fakultet Univerziteta u Beogradu, Beograd 2010, 102. It could equally be said that the disarming of voters was a prerequisite for having modern elections.
} 
The eleventh section, Knjažev poziv na skupštinu ("The Prince's call to the Assembly" - art. 80-82) concerns the Prince's formal call to the Assembly every year. The call was to contain the date and time of assembly and to be published in the official gazette, as well as in every county and district city. All MPs were obliged to commence their journey so that they would infallibly be present at the opening of the Assembly, and had to bring their credentials along. Those elected while the Assembly was already in session had to attend it as soon as they were elected.

Closely related to this was an issue that worried some MPs: what guarantees would they have that the Assembly would be convoked every year? Prior to this Constitution, in Prince Mihailo's time, it was in session only once every three years ${ }^{69}$, and some showed concern that such a practice would continue. The issue was first raised in the Assembly when it discussed the Act on parliamentary procedure, when MP Kosta Dimitrijević suggested adding an article that would stipulate that, if the Minister did not convoke the Assembly every year as the Constitution demanded, the MPs of the last convocation could assemble on their own. ${ }^{70}$ To that the Prime Minister merely replied that an act is passed for what should, and not what should not be, and that if a minister failed to convoke the Assembly, he would answer for breaking the Constitution - but that MPs gathering without a call to assembly would also be in breach of the Constitution. As multiple MPs ${ }^{71}$ expressed the view that the matter belonged in the Elections Act, the discussion was postponed. ${ }^{72}$ It was reopened the following day, but postponed again for the same reason. ${ }^{73}$

However, even before the plenary discussion, the legislative committee had reopened it on its meetings and consulted the Minister of Internal Affairs regarding it. The Minister's initial reply was purely political: he pointed out that the suspicion of a government unconstitutionally not convoking the Assembly could not be directed against the current Government, as it was the one responsible for the very passing of the Constitution. He further elaborated how the Government had demonstrated its sincere loyalty to the Constitution through preparing and

${ }^{69}$ Zakon o narodnoj skupštini, Sbornik zakona i uredba izdani' u Knjažestvu Srbiji. Od početka do konca 1861. godine, XIV, Državna štamparija, Beograd 1862, 137-146.

${ }^{70}$ His initiative was backed by Antonije Pantić, but the Chair of the Assembly Živko Karabiberović pointed out that such a provision would be better suited for the Elections Act.

${ }^{71}$ In broader terms, Stojan Veljković and, explicitly, Alimpije Vasiljević.

72 Protokoli, 60-61.

${ }^{73}$ The issue was brought up by an MP named Pavle, but mentioned without a last name: it could be either Pavle Radivojević or Pavle Grković. Dragutin Ristić suggested that the Prince be given the right to convoke the Assembly if the ministers do not do it. Kasijan Stojšić suggested that the matter be postponed until the discussion regarding the Elections Act. The proposal was seconded by the secretary of the Assembly, Alimpije Vasiljević, and subsequently accepted. Ibid., 63-64. 
proposing even more relevant acts than the Constitution demanded it to do. Regarding the matter itself, the Minister believed the solution proposed by the Assembly to be unconstitutional, since art. 76 of the Constitution expressly gave the Prince the right to convoke the Assembly and determine the time and place of its sessions. However, he continued, even if such a provision was legally possible, it would be of no practical use, because the MPs who would gather on their own initiative could do no more than compose and sign an act stating that the Assembly was not convoked in time - if the Government would propose no bills and otherwise refuse official contact with the self-gathered Assembly. He concluded that no legal provision would thus help in such cases, but merely "the developed conscience and strong character of the people" 74 , only the existence of which would help avoid what the Assembly feared. Unable to find a better solution, the committee accepted the Minister's reasoning and reported about it to the Assembly. ${ }^{75}$

Dimitrijević's proposal was addressed again during the discussion on this section of the Act. ${ }^{76}$ The legislative committee was against it, but Dimitrijević kept urging for it, stating that although he was sure that the current Government would not break the law in such a way, the issue might still prove to be relevant in the future. ${ }^{77}$ Alimpije Vasiljević stated that he was previously in favour of this proposal, but that the committee's report had convinced him that no legal norm would help in such cases, and that only the awareness of the people could overrule such political violence. Along with a few other remarks in a similar vein ${ }^{78}$, Sima Živković stated that the risk of the Government not convoking the Assembly was not great, as now no law could be passed without the Parliament, and the Government also needed it to approve the budget for each year. In the subsequent vote, Dimitrijević's proposal was rejected.

The final, twelfth section, Velika skupština ("The Great Assembly") contained only a single article detailing the specifics of elections for the Great National Assembly: these elections were held according to the same rules, except that no MPs were chosen by the Prince, and did not replace or exclude the regular elections for the ordinary Assembly. ${ }^{79}$

74, ,... razvijenoj svesti i jakom karakteru naroda...“

${ }^{75}$ Protokoli, 115-117.

76 Protokoli, 133-134.

77 "We are, he says, certain that the current Government will perform no such illegal act, but these people who are in the Government now are not immortal and eternal: an occasion may arise when we shall regret not putting this into the Act.“" (,Mi smo veli uvereni da sadanja vlada neće učiniti take nezakonitosti, ali ovi ljudi koji su sad na vladi nisu nesamrtni i večni; mogu nastati prilike kad ćemo se kajati što nismo to u zakon stavili.") Protokoli, 133.

${ }^{78}$ By Dragutin Riznić, Boža Božović and Milosav Vukomanović.

${ }^{79}$ For more information regarding this institution, see S. Jovanović, Velika narodna skupština. 


\section{CONCLUSION: INTERESTS OF AN ASSEMBLY}

The analysis shows that the main issue that concerned the members of the first legislative Parliament of Serbia regarding the Elections Act were guarantees that the Assembly would be summoned every year and that it would properly represent the interests of the people. The MPs were primarily concerned with regular sessions of the Assembly and the length of the deputies' mandate. The former issue could not be legally resolved to everyone's satisfaction, as the risk they feared was not legal to begin with, but political. Still, in such a sensitive situation (after the assassination of the old Prince and with the new one being underage and with no further heir), it could be expected that the Regency and the Government would not risk making a move that would cause such a broad wave of displeasure as not convoking the (freshly empowered) Assembly.

As for the issue of mandate length, it is obvious that the MPs' motivation was not, as one might be tempted to expect, to give themselves (or their subsequent colleagues) as long a term as possible, but to grant them the best conditions for representing the people that had elected them and to enable them to stay independent from the Prince and Government. The fact that opinions differed regarding whether that would be better accomplished by a shorter or longer term is hardly surprising, particularly in a country where a tradition of electing an Assembly for only a single session already existed. The same goal can be said to have been pursued in the addition of temporary ineligibility to the legal penalties for electoral corruption.

Another circle of issues that the Assembly was concerned with were those that could cause dissatisfaction or inconvenience to their voters. This can be seen in the discussion regarding the base electoral unit for the indirect elections, but also in the committee's refusal to make use of a dice roll in the case of a tie. The same can be said for the brief discussion regarding the number of MPs that took place during the passing of the Constitution: a smaller Assembly was objected to not directly on the grounds of being less efficient or less representative, but merely because the people would be unhappy with it. Again, tradition played an important role here: the people would be unhappy because they had already gotten used to the Assemblies being large, and they would view a significant reduction in the number of MPs as infringement of their rights.

It is noticeable that the electoral procedure itself caused very little to no discussion in the Assembly. One might assume that the particularities of registering and counting votes were too technical for the MPs to delve into in great detail, and that they deemed them to be acceptable in general. Still, it may come as a slight surprise that not even the general principles were questioned at least by the more liberal of the MPs - such as indirect elections in rural communities or, particularly, public ballots. This might at least partially be explained by them 
focusing on the aforementioned issues they believed to be more important, the general urgency of the Assembly's work, as well as the new political climate that followed the passing of the Constitution of 1869, in which the coming position of the National Assembly and the executive's attitude towards it was not yet completely clear. Furthermore, public voting had come to be seen as normal by the majority of the population, and the transfer of overall control from the police to the municipality courts was probably already seen as a loosening of the Government's grip upon the electoral process.

Overall, it can be seen that the members of the first legislative Assembly were focused on a few key issues of the Elections Act, that they demonstrated far more sensitivity regarding political than purely legal issues, and that they, at least for the most part, did not propose radical changes in the Government's draft. On the one hand, their level of education was mostly insufficient for analysing complex legal issues; on the other hand, the Constitution had already granted the Assembly a significant increase in power compared to its previous position. Tradition can also be considered a force that led them to hold on to solutions from previous laws and customs (except where those were clearly negative - e.g. the bearing of arms to elections). Still, one cannot say that the opposition was pacified and that the MPs were fully content with what they were granted: even with all the previously mentioned factors, the Assembly's main interests seem to be guaranteeing a proper representation of the people - both in the sense of the voters' satisfaction and the deputies' independence from the Prince and Government. 


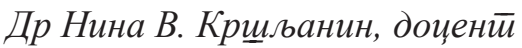

Универзитией у Беог̄раду

Правни факулиеети у Беог̄раду

nina.krsljanin@ius.bg.ac.rs

\section{Изборни закон Србије из 1870: мисли једне скупштине о парламентарним изборима}

Сажжейак: Устиав Србије из 1869. гоодине (йзв. Намеснички устиав) био

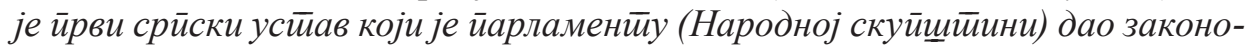
давну власти, мада је она била слабија у йоређењу са монархом. Међуйим, многее бийне йојединосиии у йог̆леду йарламенйарних избора нису одређене у Усйаву: на ирример, дужина йосланичког̄ мандайа или йийање да ли ће глла-

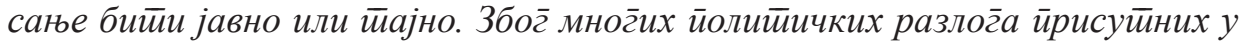

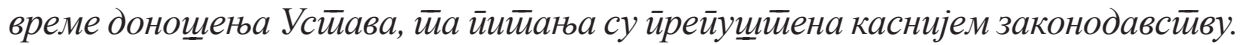

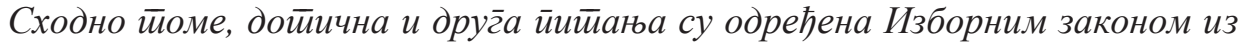
1870. голдне, који је уирраво донела иррва законодавна Скуйшимина.

У овом раду су анализирани сам Изборни закон и дебайа која се водила у Народној скуйщитини тиоком њег̄овог донощења. Нарочитиа йажња је йосвећена иичйањима о којима се водила иниеензивна скуйшиминска дискусија, као и онима гेде је Закон у већој мери одсииуиио од устиавног̄ оквира. Ауйор йокушава да објасни разлогее за увођење одређених усиианова и да йокаже како

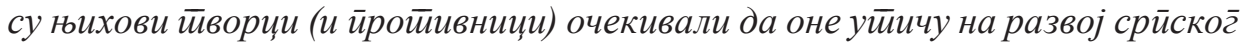
народног йредстиавнищйва.

Кључне речи: Усйав Србије из 1869. гоодине, избори за Народну скуйщйи-

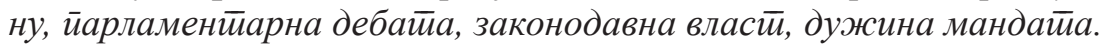

Датум пријема рада: 08.12.2018. 